\title{
Spatial analysis of road traffic accident deaths in the state of Paraná, 2007-2016
}

\author{
Análise espacial das mortes por acidentes de trânsito no estado do Paraná, 2007-2016 \\ Análisis espacial de las muertes por accidentes de tránsito en el estado de Paraná, 2007-2016
}

Received: 08/27/2021 | Reviewed: 09/02/2021 | Accept: 09/02/2021 | Published: 09/05/2021

\author{
Claudia Schneck \\ ORCID: https://orcid.org/0000-0002-7048-9572 \\ Universidade Federal do Paraná, Brazil \\ E-mail: claudiaschneck@ hotmail.com \\ Elias Teixeira Krainski \\ ORCID: https://orcid.org/0000-0002-7063-2615 \\ Universidade Federal do Paraná, Brazil \\ E-mail: eliaskrainski@gmail.com \\ Carlos Eduardo da Rocha Omoto \\ ORCID: https://orcid.org/0000-0002-6053-6697 \\ Pontifícia Universidade Católica do Paraná, Brazil \\ E-mail: omotoeduardo@gmail.com \\ Daniel Grabaski Accioly \\ ORCID: https://orcid.org/0000-0002-4681-0805 \\ Pontifícia Universidade Católica do Paraná, Brazil \\ E-mail: daniel.accioly@pucpr.edu.br \\ Faissal Nemer Hajar \\ ORCID: https://orcid.org/0000-0003-4089-1912 \\ Universidade Federal do Paraná, Brazil \\ E-mail: faissalhajar.ufpr@gmail.com \\ Vitor Cassal da Cunha \\ ORCID: https://orcid.org/0000-0002-6213-9425 \\ Pontifícia Universidade Católica do Paraná, Brazil \\ E-mail: vitor.cassal@live.com \\ Vitor Machado Guimbala \\ ORCID: https://orcid.org/0000-0002-2262-8048 \\ Pontifícia Universidade Católica do Paraná, Brazil \\ E-mail: vguimbala@hotmail.com \\ Marilisa Carneiro Leão Gabardo \\ ORCID: https://orcid.org/0000-0001-6832-8158 \\ Universidade Positivo, Brazil \\ E-mail: marilisagabardo@gmail.com \\ Solena Ziemer Kusma \\ ORCID: https://orcid.org/0000-0003-1708-0038 \\ Universidade Federal do Paraná, Brazil \\ E-mail: solenakusma@gmail.com
}

\begin{abstract}
Brazil is in fifth place among countries with the highest number of land transport accidents. The state of Paraná, Brazil, was the object of this study which conducted spatial analysis with the aim of identifying areas where this phenomenon occurs more and their time series over a 10 -year period. This was an ecological and exploratory observational study covering the period 2007 to 2016 in 39 micro-regions of the state of Paraná. Data of road traffic accident deaths as per the International Classification of Diseases (ICD-10, codes V01 to V89) held on the Mortality Information System, were analyzed. Relative risk rates were calculated and choropleth maps were built. A total of 31,651 deaths from the causes examined were recorded according to municipality of occurrence. The most frequent ICD-10 items found were those involving automobile occupants, motorcyclists, pedestrians and cyclists in road traffic accidents. An overall falling trend was found with effect from 2012. The rate by area did not show pronounced spatial dependence and there was considerable variation, whereby the Cerro Azul micro-region had the lowest relative risk in the period, while in Campo Mourão deaths were around 53.3\% above the expected level. The estimated average annual trend for the Curitiba micro-region had the steepest fall in the period, while Campo Mourão had the highest rising trend. The trend analysis indicated places where more robust public policy interventions and enforcement actions need to be reviewed.
\end{abstract}

Keywords: Spatial analysis; Traffic accidents; Mortality registries; Public policy. 


\begin{abstract}
Resumo
O Brasil ocupa o quinto lugar entre os países com maior número de acidentes de transporte terrestre. O estado do Paraná, Brasil, foi o objeto deste estudo em que foi realizada uma análise espacial com o objetivo de identificar as áreas onde esse fenômeno ocorre mais e suas séries temporais ao longo de um período de 10 anos. Tratou-se de um estudo observacional ecológico e exploratório abrangendo o período de 2007 a 2016 em 39 microrregiões do estado do Paraná. Foram analisados os dados de óbitos por acidentes de trânsito de acordo com a Classificação Internacional de Doenças (CID-10, códigos V01 a V89) do Sistema de Informações sobre Mortalidade. Taxas de risco relativas foram calculadas e mapas coropléticos foram construídos. Foram registrados 31.651 óbitos pelas causas examinadas, de acordo com o município de ocorrência. Os itens da CID-10 mais frequentemente encontrados foram aqueles envolvendo ocupantes de automóveis, motociclistas, pedestres e ciclistas em acidentes de trânsito. Constatou-se uma tendência geral de queda com efeito a partir de 2012. A taxa regional não apresentou dependência espacial acentuada e houve variação considerável, sendo a microrregião de Cerro Azul a de menor risco relativo no período, enquanto em Campo Mourão os óbitos foram em torno 53,3\% acima do nível esperado. A tendência média anual estimada para a microrregião de Curitiba apresentou a maior queda no período, enquanto Campo Mourão apresentou a maior tendência de alta. A análise de tendências indicou locais onde intervenções de políticas públicas e ações de fiscalização mais robustas precisam ser revistas.
\end{abstract}

Palavras-chave: Análise espacial; Acidentes de trânsito; Registros de mortalidade; Política pública.

\title{
Resumen
}

Brasil ocupa el quinto lugar entre los países con mayor número de accidentes de transporte terrestre. El estado de Paraná, Brasil, fue el objeto de este estudio que realizó un análisis espacial con el objetivo de identificar las áreas donde más ocurre este fenómeno y sus series de tiempo en un período de 10 años. Se trata de un estudio observacional ecológico y exploratorio que abarca el período 2007 a 2016 en 39 microrregiones del estado de Paraná. Se analizaron los datos de muertes por accidentes de tránsito según la Clasificación Internacional de Enfermedades (CIE-10, códigos V01 a V89) que se encuentran en el Sistema de Información de Mortalidad. Se calcularon las tasas de riesgo relativo y se construyeron mapas de coropletas. Se registró un total de 31.651 defunciones por las causas examinadas según municipio de ocurrencia. Los ítems de la CIE-10 más frecuentes encontrados fueron los que involucraban a ocupantes de automóviles, motociclistas, peatones y ciclistas en accidentes de tránsito. Se encontró una tendencia general a la baja con efecto a partir de 2012. La tasa por área no mostró una dependencia espacial pronunciada y hubo una variación considerable, por lo que la microrregión de Cerro Azul tuvo el riesgo relativo más bajo en el período, mientras que en Campo Mourão las muertes fueron alrededor de 53,3\% por encima del nivel esperado. La tendencia anual promedio estimada para la microrregión de Curitiba tuvo la caída más pronunciada en el período, mientras que Campo Mourão tuvo la tendencia alcista más alta. El análisis de tendencias indicó lugares donde es necesario revisar intervenciones de política pública y acciones de aplicación más sólidas.

Palabras clave: Análisis espacial; Accidentes de tránsito; Registros de mortalidad; Política pública.

\section{Introduction}

The World Health Organization has estimated that globally in 2016, 1.35 million people died as a consequence of land transport accidents - LTA (WHO, 2018); i.e. approximately 3,700 people a day. The road traffic injury control is a public health problem (Mohan, 2008), since the road traffic violence is in eighth place among the leading causes of death worldwide and leaves some 50 million people injured, according to the Global Status Report on Road Safety 2018 (WHO, 2018). Also, the number of occurrences is disproportionate in developing countries (Nantulya \& Reich, 2002), revealing inequalities (Nantulya \& Reich, 2003), with worse conditions for populations from India (India State-Level Disease Burden Initiative Road Injury Collaborators, 2020), and Latin America (Martínez, Contreras, \& Moreno, 2020), and Africa (Adeloye, Thompson, Akanbi, Azuh, Samuel, \& Omoregbe, 2016) countries.

In Brazil, road traffic deaths reached their highest level in 2012, totaling 44,812 victims. However, there has been a falling trend since then, with 35,375 deaths recorded in 2017 and a reduction of $21.05 \%$, according to the Mortality Information System (http://sim.saude.gov.br/default.asp). The Global Burden of Disease Study 2015 found that Brazil had the second highest Disability-Adjusted Life Years rate for LTAs (1,230 per 100,000 inhabitants in 2015) among the South American countries (GBD 2015 Disease and Injury Incidence and Prevalence Collaborators, 2016).

According to a report by the Brazilian Institute of Applied Economic Research - Instituto de Pesquisa Econômica Aplicada (IPEA), the cost of road traffic accidents in terms of public expenditure is estimated to be around BRL 40 billion per 
annum for highway accidents and BRL 10 billion per annum for urban roads and street accidents (IPEA, 2015). The greatest cost relates to lost productivity, due to time off work or death, with impacts on Social Security and families, followed by health expenditure, overburdening emergency, hospital and rehabilitation services (Andrade \& Mello-Jorge, 2016).

Alcohol intake is one of the main risk factors associated with road traffic accidents (Barone et al., 2019; Borges et al., 2017; Das, Gjerde, Gopalan, \& Normann, 2012; Valen et al., 2019). Thus, in order to be minimized the consequences of this interaction, public policies were adopted by governments, through the reduction of the permitted level of blood alcohol, or by the prohibition of any blood alcohol content (Fell \& Voas, 2014; Nagata, Setoguchi, Hemenway, \& Perry, 2008; Nistal-Nuño, 2017).

In the Brazilian context, some positive evidence of these strategies has also been identified (Andreuccetti, Carvalho, Cherpitel, Ye, Ponce, Kahn, \& Leyton., 2011; Malta, Berna, Silva, Claro, Silva Júnior, \& Reis, 2014). The Brazilian Traffic Code, instituted by Law No. 9503/1997 (Brasil, 1997), allowed, with no penalties, up to 6 decigrams of alcohol per litre of blood, which is the equivalent of two measures $(80 \mathrm{ml})$ of distilled drink. In order to come into line with the global reality of greater restraint, the so-called Dry Law (Law No. 11705/2008) altered the Highway Code and established zero tolerance of blood alcohol content, stiffer penalties for drivers and restrictions on the sale of alcoholic beverages on federal highways (Brasil, 2008a). In 2012, the New Dry Law (Law No. 12760/2012) introduced innovations regarding some topics provided for by the previous Dray Law, such as proving alcohol consumption by the use or otherwise of the blood alcohol measurement device (breathalyzer) (Brasil, 2012). Finally, in 2016, Law No. 13281 introduced a new article for the offense of refusing to have a breathalyzer test (Brasil, 2016).

The Life in the Traffic Project (Projeto Vida no Trânsito) began in 2012, being a version of the Road Safety in Ten Countries (RS-10) project funded by the Bloomberg Philanthropies Foundation (Bloomberg Philanthropies, 2013). and adapted to Brazilian reality, coordinated by the Ministry of Health and involving other government bodies (Brasil, 2017; Curitiba, 2010; UN Road Safety Collaboration, 2020). Its objective is to plan and enhance road traffic safety strategies, which involves actions at the federal, state and municipal levels (Morais Neto et al., 2013). The project was initially implemented in five state capitals, one in each of the country's five macro-regions. In 2013 it was expanded to municipalities with more than one million inhabitants and to all the country's remaining state capitals (Curitiba, 2010; UN Road Safety Collaboration, 2020). In the state of Paraná, Curitiba was the first city to take part in the program and by 2017 a further 12 of the state's cities were taking part (Paraná, 2019).

Paraná has a high LTA mortality rate, of 30.3, occupying the first position in Brazilian's South and Southeast regions (Ladeira et al., 2017). At the national level, occupies the third position in the register of accidents with victims (CNT, 2018). Also, it is a state located in a cluster considered to be of high risk, as it has a large number of municipalities bordering other states in the country, which has a statistically significant impact on the number of deaths from road traffic accidents (Morais Neto et al., 2012).

Thus, the aim of this study was to identify the spatial distribution of deaths due to road traffic accidents in Paraná, from 2007 to 2016, according to the state's micro-regions.

\section{Methodology}

This was an ecological and exploratory observational study covering the period 2007 to 2016 in 39 micro-regions of the state of Paraná. Data of road traffic accident deaths as per the International Classification of Diseases (ICD-10, codes V01 to V89) (WHO, 2016) held on the Mortality Information System (http://sim.saude.gov.br/default.asp), were analyzed.

Relative risk (RR) rates were calculated and choropleth maps were built. Annual trend was analyzed using a statistical model considering the neighboring structures of the micro-regions. Data on all causes covered by ICD-10 (codes V01 to V89) 
were also studied by micro-region and by year. The population in each micro-region as per the 2010 census (IBGE, 2010) was used to calculate mortality rates.

$\mathrm{RR}$ is a measurement commonly used to map diseases, being the ratio between the number of deaths recorded and the number of deaths expected, calculated according to a given criterion (Pereira, 2008). It is common to consider the expected number of deaths as being the result of the death rate in a period and total area multiplied by the population in each study area and period. As such, the overall rate in Paraná during the entire analysis period and the population as counted by the 2010 census (IBGE, 2010) were recorded.

In order to model the Standardized Mortality Rate, it was considered that the rate in each micro-region varies, so that neighboring micro-regions tend to have similar rates. In addition, it was considered growth of the rate in each micro-region assuming this occurrence similar to that of its neighboring micro-regions. This is the model validated by Castro et al. (2004).

As such, the formula for occurrence in micro-region $i$ in time $t, o_{i, t}$ is:

$$
o_{i, t} \sim \operatorname{Poisson}\left(E_{i} r_{i, t}\right)
$$

where $E_{i}$ is the expected number of deaths in micro-region $i$ and $r_{i, t}$ is RR. The statistical model considers that the risk logarithm is defined by:

$$
\log \left(r_{i, t}\right)=\alpha_{i}+\beta_{i} t
$$

where $\alpha_{i}$ is an intercept or reference rate (for the first year) and $\beta_{i}$ expresses annual relative growth. This means that there is a rate for each area and time which is being modeled by a rate in each area in the first year plus annual growth particular to each micro-region.

When specifying the statistical model for $\alpha_{i}$ and $\beta_{i}$, the proposal recommended by Riebler et al. (2016) was taken into account. In this case, for example, the following formula for $\alpha_{i}$ was:

$$
\alpha_{i}=\sigma_{\kappa}\left(\sqrt{\phi_{\alpha}} u_{i}+\sqrt{1-\phi_{\alpha}} v_{i}\right)
$$

where $\alpha$ has two terms: $v$ and $u$. The term $u$ is assumed to be similar for neighboring areas in order to capture possible regional variations, and the term $v$ is not structured in space in order to capture variations particular to each municipality. Term $v$ has variance of 1 , that is to say, $v_{i} \sim N(0,1)$, while $u$ is standardized in order to obtain marginal variance equal to 1 (one); however, each $u_{i}$ depends on the $u$ values in the neighboring areas. These two terms are weighted by the $\phi_{\alpha}$ parameter, this being a parameter that measures the proportion of the spatial effect structured in space and is associated with the degree of spatial correlation. The term $\sigma_{a} l p h a$ measures the extent of the influence of the $\alpha$ effect, 
whereby the greater this value, the greater the variation of $\alpha$, indicating greater variation in the rate between micro-regions.

Similarly, there is:

$$
\beta_{i}=\sigma_{\beta}\left(\sqrt{\phi_{\beta}} r_{i}+\sqrt{1-\phi_{\beta}} s_{i}\right)
$$

where $r$ and $s$ have properties like those of $u$ and $v$, respectively. In order to complete the specification of the model in accordance with the paradigm of the Bayesian model, it was considered a priori distribution for the $\sigma_{\alpha}, \phi_{\alpha}, \sigma_{\beta}$ e $\phi_{\beta}$, and parameters, taking into account shape complexity penalization as per Simpson et al. (2017) and as per Riebler et al. (2016) For the a posteriori calculation of marginal distributions, it was used the Integrated Nested Laplace Approximations (INLA) algorithm proposed by Rue et al. (2009), using the INLA package (www.r-inla.org).

\section{Results}

The map of Paraná's micro-regions, with their respective resident population (expressed in thousands) in 2010 are shown in Figure 1. In 2010, Paraná's population was estimated to be 10,444,526 inhabitants. As such, the annual road traffic accident death rate in the same year was 33.0 per 100,000 inhabitants.

Figure 1. Map of Paraná's micro-regions and their respective resident populations expressed in thousands in 2010.

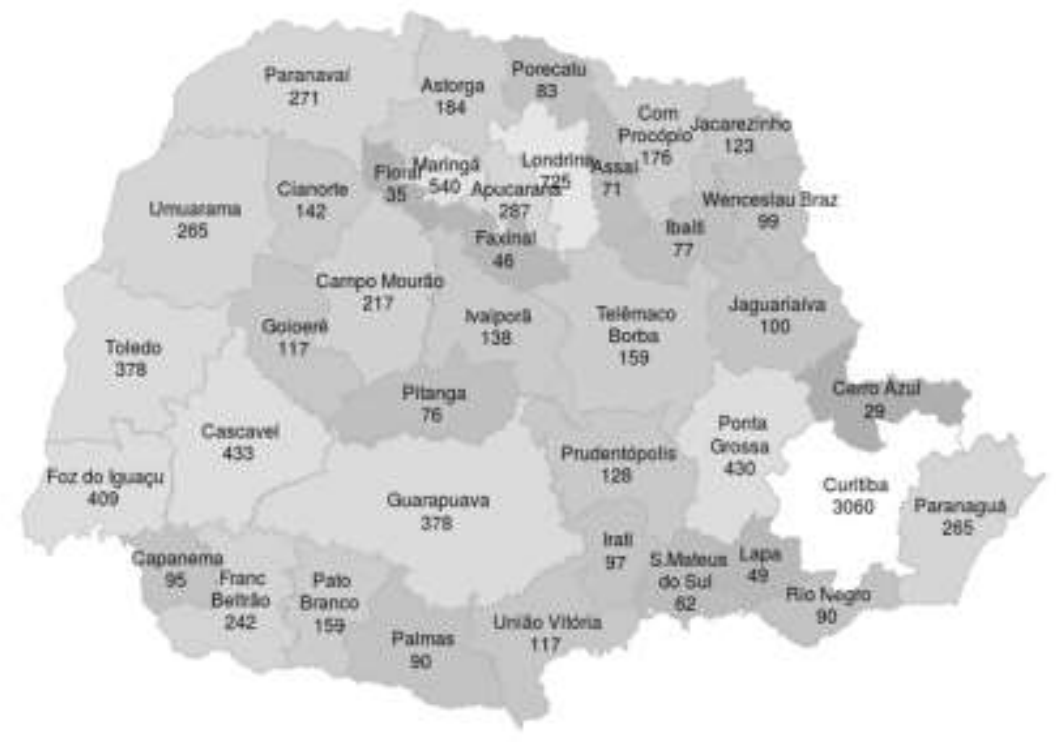

Source: IBGE (2010).

There were 31,651 deaths in Paraná according to the data analyzed. The number of deaths each year and respective crude annual rate per 100,000 inhabitants can be seen in Table 1, showing a reduction in values from 2014. 
Table 1. Annual number of deaths and rate per 100,000 inhabitants in Paraná.

\begin{tabular}{lllllllllll}
\hline & $\mathbf{2 0 0 7}$ & $\mathbf{2 0 0 8}$ & $\mathbf{2 0 0 9}$ & $\mathbf{2 0 1 0}$ & $\mathbf{2 0 1 1}$ & $\mathbf{2 0 1 2}$ & $\mathbf{2 0 1 3}$ & $\mathbf{2 0 1 4}$ & $\mathbf{2 0 1 5}$ & $\mathbf{2 0 1 6}$ \\
\hline Deaths & 3196 & 3217 & 3134 & 3442 & 3365 & 3629 & 3168 & 3076 & 2678 & 2746 \\
Rate & 30.6 & 30.8 & 30.0 & 33.0 & 32.2 & 34.7 & 30.3 & 29.5 & 25.6 & 26.3 \\
\hline
\end{tabular}

Source: Mortality Information System and IBGE (2010).

The rates in the maps shown in Figure 2 were categorized. This made it possible to organize the micro-regions by rate groups for each year studied.

Figure 2. Sequence of maps showing estimated RR by micro region.
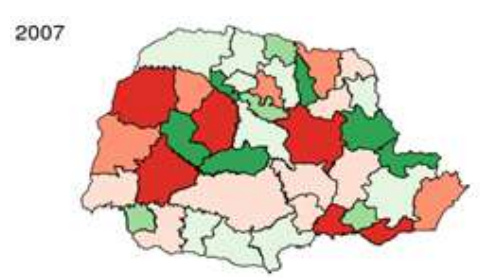

2009

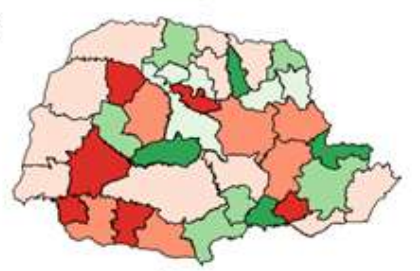

2011

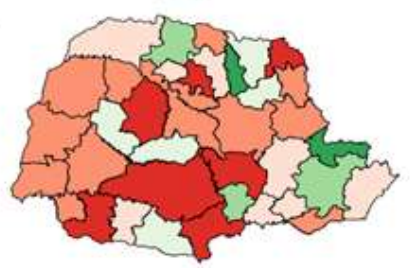

2013

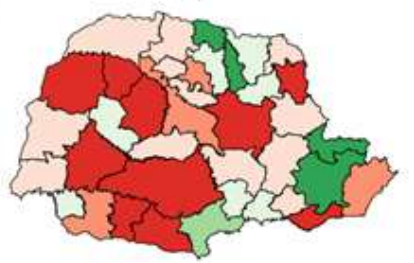

2015

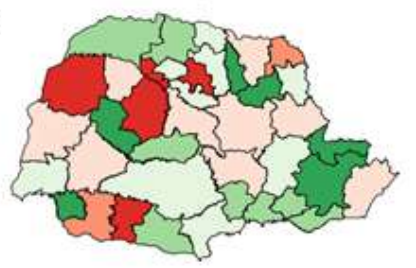

2008

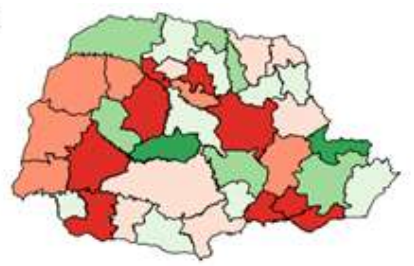

2010

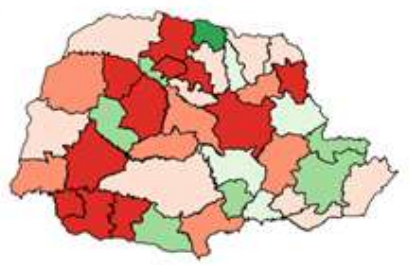

2012

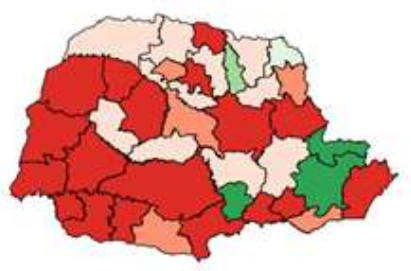

2014

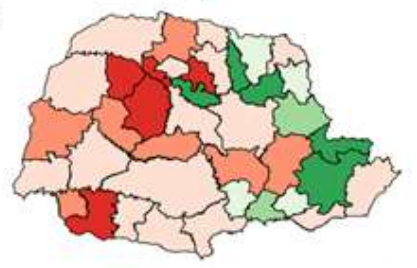

2016

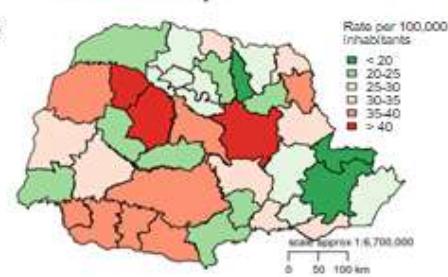

Source: Map adapted (Paraná, 2016).

A fall in the RR rates can be seen between 2013 and 2016 in the majority of Paraná's micro-regions. It is noteworthy that in 2012, the rate in 18 micro-regions was above 40 per 100,000 inhabitants. However, the number of micro-regions with this status fell to just 3 in 2016. In addition, there was a greater frequency of micro-regions in the higher rate categories up until 2013, while a lower number of micro-regions had high rates after 2013 (Figure 2 and Table 2). 
Table 2. Number of micro-regions in each rate group by year.

\begin{tabular}{lcccccccccc}
\hline Rates* & $\mathbf{2 0 0 7}$ & $\mathbf{2 0 0 8}$ & $\mathbf{2 0 0 9}$ & $\mathbf{2 0 1 0}$ & $\mathbf{2 0 1 1}$ & $\mathbf{2 0 1 2}$ & $\mathbf{2 0 1 3}$ & $\mathbf{2 0 1 4}$ & $\mathbf{2 0 1 5}$ & $\mathbf{2 0 1 6}$ \\
\hline up to 20 & 6 & 2 & 4 & 1 & 2 & 3 & 4 & 5 & 6 & 3 \\
$20-25$ & 4 & 6 & 6 & 6 & 3 & 1 & 1 & 2 & 8 & 8 \\
$25-30$ & 10 & 9 & 6 & 4 & 5 & 1 & 7 & 4 & 9 & 9 \\
$30-35$ & 8 & 7 & 11 & 10 & 8 & 11 & 12 & 16 & 9 & 8 \\
$35-40$ & 5 & 6 & 6 & 7 & 14 & 5 & 5 & 7 & 2 & 8 \\
over 40 & 6 & 9 & 6 & 11 & 7 & 18 & 10 & 5 & 5 & 3 \\
\hline
\end{tabular}

Note:* per 100,000 inhabitants.

Source: Mortality Information System and IBGE (2010).

Figure 3A shows the map of the crude rate per 100,000 inhabitants, found in each micro-region for the entire period (2007-2016). Figure 3B shows estimated RR per micro-region. The micro-region with the lowest estimated RR in the period was Cerro Azul (65.9\% fewer deaths), while Campo Mourão had the highest estimated RR (53.3\% more deaths).

Figure $3 \mathrm{C}$ shows the estimated average annual mortality rate rising (or falling) trend. The Curitiba micro-region can be seen to have had the largest fall in the period, with an average annual falling trend of 5.4\%, while Campo Mourão had the highest rising trend in the period, with an average annual increase of $1.3 \%$ over the 10 -year period. It can be seen that there are no micro-regions with annual growth greater than 3\%, while the rate fell by more than $3 \%$ in three micro-regions (Cerro Azul, Curitiba and Rio Negro).

Figure 3. Map of the crude rate found for each micro-region (A); Map of estimated RR per micro-region (B); Estimated average annual mortality rate rising (or falling) trend per micro-region (C).

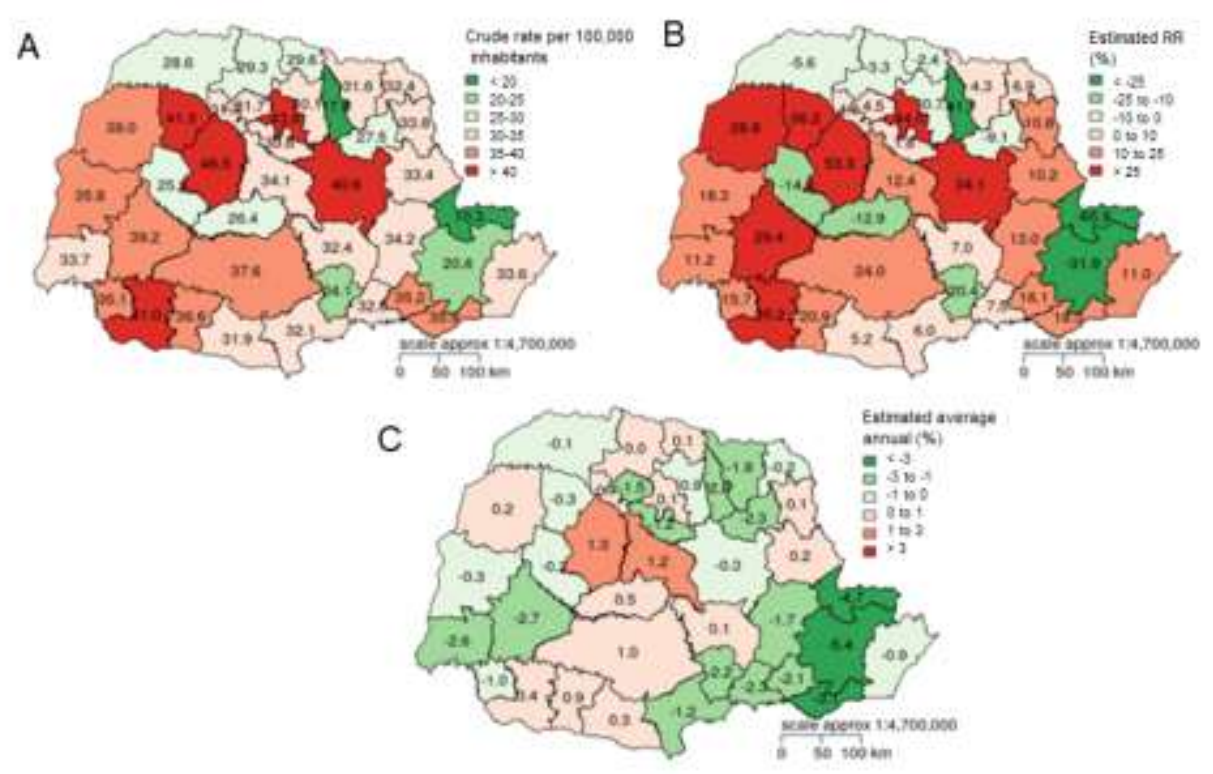

Source: Map adapted (Paraná, 2016).

\section{Discussion}

This study aimed to evaluate the RR and to conduct a spatial analysis of the areas of the state of Paraná, according to road traffic accident data, from 2007 to 2016. The most frequent ICD-10 items found involved automobile occupants, motorcyclists, pedestrians, and cyclists. The spatial analysis revealed a variation, with areas with low RR, such as Cerro Azul, 
and with high RR, such as Campo Mourão.

The justification for choosing the state of Paraná is due to that this state is among the worst in terms of road accident indicators in Brazil, occupying the third national position and the first in the southern region of the country (CNT, 2018; Ladeira et al., 2017). The state is also located in a cluster of municipalities considered to be at high risk for accidents, since many of these municipalities border with municipalities in other states, which determines an extensive road network (Morais Neto et al., 2012).

In 2010 the United Nations Organization defined the period from 2011 to 2020 as the Decade of Action for Road Safety, creating a plan with sustainable targets to be met in order to reduce by half the number of deaths caused by road traffic accidents. This initiative aims to save lives by building and maintaining good highway infrastructure, developing safer vehicles, improving driving behavior and optimizing post-accident care (UN Road Safety Collaboration, 2020).

It is important to mention that road traffic accidents burden the governments, with expenses that can vary, in high income countries from $0.5 \%$ to $6.0 \%$ of the GDP, while in low and middle income countries, this value varies from $1.1 \%$ to $2.9 \%$ (Wijnen \& Stipdonk, 2016).

Evidences indicate an association between alcohol consumption and road traffic accidents (Barone et al., 2019; Borges et al., 2017; Das, Gjerde, Gopalan, \& Normann, 2012; Valen et al., 2019), and a recent study revealed that drug and alcohol use may be under-reported in road accident records (Rolison, Regev, Moutari, \& Feeney, 2018).

In Brazil, public policies, implementation and enforcement of national restrictive legal measures on drink-driving (Brasil, 2000, 2008b), appear to have been effective over the years, especially after the Dry Law (Brasil, 2008a) was implemented, this being a possible hypothesis for the fall in the RR rates, especially between 2013 and 2016, in most of the micro-regions of the state of Paraná.

However, it is necessary to discuss the role that these alcohol regulatory measures play in coping with traffic deaths and injuries. Although in the Brazilian context the impact was perceived after the implementation of such measures, this occurred in the periods immediately after the restrictive measures. In the following months, there was a trend of stability and increase in traffic deaths in the country, which indicates an inability to fully control it, which becomes a controversial topic (Morais Neto et al., 2013). In Chile, for example, the same occurred, with a more pronounced decline after the law in relation to alcohol-related deaths, but these differences were not statistically significant (García-Echalar \& Rau, 2020).

Some countries have also identified that blood alcohol regulation has not resulted in a reduction in accidents. A natural experiment, using data on road traffic accidents and alcohol consumption in Scotland (interventional group - the blood alcohol concentration limit for drivers was reduced from $0.08 \mathrm{~g} / \mathrm{dL}$ to $0.05 \mathrm{~g} / \mathrm{dL}$ in 2014) and England and Wales (control group). Authors found that lowering alcohol concentration in Scotland was not associated with a reduction in road traffic accidents, but it was associated with a small reduction a reduction in the purchase of alcoholic beverages (Haghpanahan et al., 2019). Ferris et al. (2017) analyzed a 10-year period of data of serious road injuries, and concluded that policies and procedures implemented to decrease drink-driving have not reduced alcohol-related serious road injuries rates.

These differences maybe can be explained by the fact that Brazil is a developing country, and so regulatory measures appear to be more effective, contrary to what is found in some developed countries. However, other measures are identified as capable of positively impacting the reduction of accidents such as education campaigns (Bon de Sousa, Santos, Mateus, Areal, Trigoso, \& Nunes, 2016), improvement of the road network, and traffic management (Sun, Liu, Chen, \& He, 2019).

In the present study, analysis on three levels is needed in order to gain a more complete panorama of the RR results in the 39 micro-regions of Paraná, between 2007 and 2016, were: the main highway network, demographic density and an indicator (e.g. estimated RR). It is suggested that the existence of main highways increases the likelihood of LTA-related deaths. This hypothesis would be sufficient to provide an explanation for the greater part of Paraná's territory, such as the 
central and western regions. However, this two-dimensional analysis of the problem is not sufficient to explain situations such as the east and part of the northeast regions of the state - which have considerable main highways but low relative risk when compared to the other regions of the state. Especially in the micro-region where the state capital, Curitiba, is located, the Life in the Traffic Project has been in operation since 2010. This factor may by the differential for it being the micro-region with the biggest drop in the mortality rate in the period studied, when considering the falling trend rate data (CNT, 2018).

Another level to be considered is demographic density, which is inversely proportional to RR, possibly because of the presence of more resources and law enforcement. Indicators, such as RR, are directly proportional to the presence of main highways, and inversely proportional to demographic density (IBGE, 2017).

The city of Cerro Azul achieved the best overall indicators, while Campo Mourão had the worst results. Two arguments are key to supposing why the first one was successful: not having high population density, but not being distant from large urban centers (located at around 2 hours from Curitiba and 3 hours from Ponta Grossa) and not being on any main highway. These are factors that must have contributed to success in reducing deaths over time following the implementation of the Dry Law in 2008 (Brasil, 2008a).

The result found for the Campo Mourão micro-region is probably related to it being crossed by the BR-158 highway, known in the period studied as being one of Brazil's most dangerous highways and having the highest number of deaths per 100 accidents in Paraná. It should be emphasized that this stretch of highway is part of the Paraná Integration Ring Road, formed by the state's main highways. The Integration Ring Road is divided into six sections, administered by six outsourced companies.

Some of this study's limitations which may act as confounding factors include: the specific accident (event) site, whether in urban areas or on open highways, given that the governmental database does not detail this information and, above all, death certificates do not provide information on the site of the event and death may occur in places other than the site of the accident; periods of heavier traffic such as summer holidays and the presence of one-off actions such as police inspection road blocks, like "Summer Operation" when these actions are organized more frequently at year-end, whereby the seasonality of such programs is not included in the time unit used.

Finally, the data was not submitted to standard correction considering the increase in the fleet of vehicles in Paraná, nor standard correction of the specific rates of type of vehicle used at the time of LTAs. Moreover, population projections for each year studied were also not used.

These data demonstrate the need to understand and act on the phenomenon, because identifying regions of greater vulnerability enables the establishment of more efficient public policies, with the aim of contributing to minimizing harm and meeting globally agreed targets. The benefits generated by a set of appropriate public interventions not only result in less costs for the health system, but fundamentally save lives (Banstola \& Mytton, 2017; Wijnen \& Stipdonk, 2016).

\section{Conclusion}

The spatial analysis data on deaths due to road traffic accidents in the state of Parana are particularly relevant for the Federal Administration, as evidence of weak points that need to be reviewed, as well as the need to conduct new studies in this area. Moreover, it is a pioneer study in the state, which contributes to analysis of the annual trend and provides important considerations about the panorama for forthcoming years, serving as an indicator for new public interventions. Future research can be done in order to strengthen relations with agencies related to traffic control, as well as the expansion and applicability of the method in other Brazilian municipalities. 


\section{References}

Adeloye, D., Thompson, J. Y., Akanbi, M. A., Azuh, D., Samuel, V., \& Omoregbe, C. K. (2016). The burden of road traffic crashes, injuries and deaths in Africa: a systematic review and meta-analysis. Bull World Health Organ, 94(7), 510-521A.

Andrade, S. S. C. A., \& Mello-Jorge, M. H. P. (2016). Mortality and potential years of life lost by road traffic injuries in Brazil, 2013. Rev Saúde Pública, 50, 59 .

Andreuccetti, G., Carvalho, H. B., Cherpitel, C. J., Ye, Y., Ponce, J. C., Kahn, T., \& Leyton V. (2011). Reducing the legal blood alcohol concentration limit for driving in developing countries: a time for change? Results and implications derived from a time-series analysis (2001-10) conducted in Brazil. Addiction, 106(12), 2124-2131.

Banstola, A., \& Mytton, J., 2017. Cost-effectiveness of interventions to prevent road traffic injuries in low- and middle-income countries: A literature review. Traffic Inj Prev, 18(4), 357-362.

Barone, R., Pelletti, G., Garagnani, M., Giusti, A., Marzi, M., Rossi, F., Roffi, R., Fais, P., \& Pelotti, S. (2019). Alcohol and illicit drugs in drivers involved in road traffic crashes in Italy. An 8-year retrospective study. Forensic Sci Int, 305, 110004.

Bloomberg Philanthropies. (2013). Leading the worldwide movement to improve road safety. Bloomberg Philantropies.

Bon de Sousa, T., Santos, C., Mateus, C., Areal, A., Trigoso, J., \& Nunes, C. (2016). Road traffic accidents and self-reported Portuguese car driver's attitudes, behaviors, and opinions: Are they related? Traffic Inj Prev, 17(7), 705-711.

Borges, G., Monteiro, M., Cherpitel, C. J., Orozco, R., Ye, Y., Poznyak, V., Peden, M., Pechansky, F., Cremonte, M., Reid, S. D., \& Mendez, J. (2017). Alcohol and road traffic injuries in Latin America and the Caribbean: A case-crossover study. Alcohol Clin Exp Res, 41(10), 1731-1737.

Brasil. (1997). Lei n. 9.503, de 23 de setembro de 1997. Institui o Código de Trânsito Brasileiro. https://www2.camara.leg.br/legin/fed/lei/1997/lei-9503-23setembro-1997-372348-publicacaooriginal-1-pl.html

Brasil. (2000). Ministério da Saúde. Política Nacional de Redução da Morbimortalidade por Acidentes e Violência. Rev Saúde Pública, 34(4), 427-430.

Brasil. (2008a). Presidência da República. Casa Civil. Subchefia para Assuntos Jurídicos. Lei n. 11.705 de 19 de junho de 2008. http://www.planalto.gov.br/ccivil_03/_ato2007-2010/2008/lei/111705

Brasil. (2008b). Conselho Nacional de Trânsito. Resolução n. 277, de 28 de maio de 2008. https://www.legisweb.com.br/legislacao/?id=108959

Brasil. (2012). Presidência da República. Casa Civil. Subchefia para Assuntos Jurídicos. Lei n. 12.760, de 20 de dezembro de 2012. http://www.planalto.gov.br/ccivil_03/_ato20112014/2012/lei/112760.htm

Brasil. (2016). Presidência da República. Secretaria-Geral. Subchefia para Assuntos Jurídicos. Lei n. 13.281, de 04 de maio de 2016. http://www.planalto.gov.br/ccivil_03/_ato2015-2018/2016/lei/113281.htm

Brasil. (2017). Ministério da Saúde. Projeto Vida no Trânsito. http://www.saude.gov.br/saude-de-a-z/acidentes-e-violencias/41896-projeto-vida-no-transito

Castro, M. S. M., Vieira, V. A., \& Assunção, R. M. (2004). Padrões espaço-temporais da mortalidade por câncer de pulmão no sul do Brasil. Rev Bras Epidemiol, 7(2), 131-143.

Confederação Nacional do Transporte (CNT). (2018). Acidentes rodoviários e infraestrutura. http://repositorio.itl.org.br/jspui/handle/123456789/170

Curitiba. (2010). Prefeitura Municipal. Secretaria Municipal de Saúde. Programa Vida no Trânsito. https://midtransito.curitiba.pr.gov.br/2019/6/pdf/00000759.pdf

Das, A., Gjerde, H., Gopalan, S. S., \& Normann, P. T. (2012). Alcohol, drugs, and road traffic crashes in India: a systematic review. Traffic Inj Prev, 13(6), 544-553.

Fell, J. C., \& Voas, R. B. (2014). The effectiveness of a 0.05 blood alcohol concentration (BAC) limit for driving in the United States. Addiction, 109(6), 869874.

Ferris, J., Killian, J., \& Lloyd, B. (2017). Alcohol-related serious road traffic injuries between 2000 and 2010: A new perspective to deal with administrative data in Australia. Int J Drug Policy, 43, 104-112.

García-Echalar, A., \& Rau, T. (2020). The effects of increasing penalties in drunk driving laws-evidence from Chile. Int J Environ Res Public Health, 17(21), 8103.

GBD 2015 Disease and Injury Incidence and Prevalence Collaborators. (2016). Global, regional, and national incidence, prevalence, and years lived with disability for 310 diseases and injuries, 1990-2015: a systematic analysis for the Global Burden of Disease Study 2015. Lancet, 388(10053), 1545-1602.

Haghpanahan, H., Lewsey, J., Mackay, D.F., McIntosh, E., Pell, J., Jones, A., Fitzgerald, N., \& Robinson, M. (2019). An evaluation of the effects of lowering blood alcohol concentration limits for drivers on the rates of road traffic accidents and alcohol consumption: a natural experiment. Lancet, 393(10169), 321329.

India State-Level Disease Burden Initiative Road Injury Collaborators, 2020. Mortality due to road injuries in the states of India: the Global Burden of Disease Study 1990-2017. Lancet Public Health, 5(2), e86-e98.

Instituto Brasileiro de Geografia e Estatística (IBGE) (2010). Censo demográfico 2010. https://censo2010.ibge.gov.br/ 
Instituto Brasileiro de Geografia e Estatística (IBGE). (2017). Cidades. https://cidades.ibge.gov.br/pesquisas

Instituto de Pesquisa Econômica Aplicada (IPEA). (2015). Estimativa dos custos dos acidentes de trânsito no Brasil com base na atualização simplificada das pesquisas anteriores do Ipea: relatório de pesquisa. http://repositorio.ipea.gov.br/bitstream/11058/7456/1/RP_Estimativa_2015.pdf

Ladeira, R. M., Malta, D. C., Morais Neto, O. L., Montenegro, M. M. S., Soares Filho, A. M., Vasconcelos, C. H., Mooney, M., \& Naghavi, M. (2017). Acidentes de transporte terrestre: estudo Carga Global de Doenças, Brasil e unidades federadas, 1990 e 2015. Rev Bras Epidemiol, 20 (Suppl 1), 157-170.

Malta, D. C., Berna, R. T. I., Silva, M. M. A., Claro, R. M., Silva Júnior, J. B., \& Reis, A. S. C. (2014). Consumo de bebidas alcoólicas e direção de veículos, balanço da lei seca, Brasil 2007 a 2013. Rev Saúde Pública, 48(4), 692-696.

Martínez, P., Contreras, D., \& Moreno, M. (2020). Safe mobility, socioeconomic inequalities, and aging: A 12-year multilevel interrupted time-series analysis of road traffic death rates in a Latin American country. PLoS One, 15(1), e0224545.

Mohan, D. (2008). Road traffic injuries: a stocktaking. Best Pract Res Clin Rheumatol, 22(4), 725-739.

Morais Neto, O. L., Montenegro, M. M. S., Monteiro, R. A., Siqueira Júnior, J. B. Silva, M. M. A., Lima, C. M. et al., 2012. Mortalidade por acidentes de transporte terrestre no Brasil na última década: tendência e aglomerados de risco. Ciênc Saúde Coletiva, 17(9), 2223-2236.

Morais Neto, O. L., Silva, M. A. A., Lima, C. M., Malta, D. C., \& Silva Jr, J. B. (2013). Projeto Vida no Trânsito: avaliação das ações em cinco capitais brasileiras, 2011-2012. Epidemiol Serv Saúde, 22(3), 373-382.

Nagata, T., Setoguchi, S., Hemenway, D., \& Perry. M. J. (2008). Effectiveness of a law to reduce alcohol-impaired driving in Japan. Inj Prev, 14(1), 19-23.

Nantulya, V. M., \& Reich, M. R. (2002). The neglected epidemic: road traffic injuries in developing countries. BMJ, 324(7346), 1139-1141.

Nantulya, V. M., \& Reich, M. R. (2003). Equity dimensions of road traffic injuries in low- and middle-income countries. Inj Control Saf Promot, 10(1-2), 1320 .

Nistal-Nuño, B. (2017). Impact of a new law to reduce the legal blood alcohol concentration limit - A Poisson regression analysis and descriptive approach. $J$ Res Health Sci, 17(1), e00374.

Paraná. (2006). Instituto Paranaense de Desenvolvimento Econômico e Social. Os vários paranás: identificação de espacialidades socioeconomicoinstitucionais como subsídio a políticas de desenvolvimento regional. IPARDES.

Paraná. (2019). Secretaria de Saúde. Projeto Vida no Trânsito. http://www.saude.pr.gov.br/modules/conteudo/conteudo.php?conteudo=3421

Pereira, M. G. (2008). Epidemiologia: teoria e prática. Guanabara Koogan.

Riebler, A., Sørbye, S. H., Simpson, D., \& Rue, H. (2016). An intuitive Bayesian spatial model for disease mapping that accounts for scaling. Stat Methods Med Res, 25(4), 1145-1165.

Rolison, J. J., Regev, S., Moutari, S., \& Feeney, A. (2018). What are the factors that contribute to road accidents? An assessment of law enforcement views, ordinary drivers' opinions, and road accident records. Accid Anal Prev, 115, 11-24.

Rue, H., Martino, S., \& Chopin, N. (2009). Approximate bayesian inference for latent gaussian models using integrated nested laplace approximations (with discussion). J R Stat Soc, 71(2), 319-392.

Simpson, D., Rue H., Riebler, A., Martins, T. G., \& Sørbye, S. H. (2017). Penalising model component complexity: a principled, practical approach to constructing priors. Statist Sci, 32(1), 1-28.

Sun, L. L., Liu, D., Chen, T., \& He, M. T. (2019). Road traffic safety: An analysis of the cross-effects of economic, road and population factors. Chin J Traumatol, 22(5), 290-295.

UN Road Safety Collaboration, 2020. Global Plan for the Decade of Action for Road Safety 2011-2020. https://www.who.int/roadsafety/decade_of_action/plan/plan_english.pdf?ua=1

Valen, A., Bogstrand, S. T., Vindenes, V., Frost, J., Larsson, M., Holtan, A., \& Gjerde, H. (2019). Driver-related risk factors of fatal road traffic crashes associated with alcohol or drug impairment. Accid Anal Prev, 131, 191-199.

Wijnen, W., \& Stipdonk, H. (2016). Social costs of road crashes: An international analysis. Accid Anal Prev, 94, 97-106.

World Health Organization (WHO). (2016). International Statistical Classification of Diseases and Related Health Problems $10 t h$ Revision. Version 2016. https://icd.who.int/browse10/2016/en

World Health Organization (WHO). (2018). Management of noncommunicable diseases, disability, violence and injury prevention. Road safety reporty 2018 global status report on road safety. https://www.who.int/violence_injury_prevention/road_safety_status/2018/ 